\title{
THE ISLAMIC FUNDAMENTALISM BASED ON KAREN ARMSTRONG'S PERSPECTIVE AND ITS IMPLICATIONS FOR THE IDENTIFICATION OF FUNDAMENTALISM GROUPS IN INDONESIA
}

\author{
Neli Rahmah \\ Fakultas Ushuluddin, Adab dan Dakwah, IAIN Bukittinggi, Indonesia \\ e-mail: Nelirabmab1227@gmail.com \\ Nelmaya \\ Fakultas Ushuluddin, Adab dan Dakwah, IAIN Bukittinggi, Indonesia \\ e-mail:Nelmaya@yahoo.co.id

\begin{abstract}
One of the developments at the end of the twentieth century was the emergence of a militant piety popularly called "fundamentalism" in each religious tradition. This term was also used to indicate a new movement in the Islamic revival. Karen Armstrong stated three characteristics of the fundamentalism movement, including Islamic fundamentalism. First, the movements of ideology and theology came of the fear. Second, these movements were not old things, but they were modern, innovative and modernizing movements. Third, the fundamentalism groups had a textual understanding of religion. Armstrong's perspective on Islamic fundamentalism had implications for the Islamic Defenders Front (FPI) and the Indonesian Mujahidin Council (MMI) which could be identified as Islamic fundamentalism groups in Indonesia. The mainspring of the emergence of FPI and MMI was as the response (read: fear) to foreign forces that threatened and made Muslims suffered for a long time. The forms of movements and actions of FPI and MMI were so organized and used the spirit of the masses to respond to actual problems in the community that were sometimes missed by the authorities. As well as the interpretation of the concept of amar ma'ruf nahi munkar was promoted by FPI and the affirmation of MMI related to the prohibition on the use of logical reasoning in text interpretation. Those facts made these two groups legitimate as fundamentalism groups within the framework of Karen Armstong's analysis.
\end{abstract}

Keywords: Islamic Fundamentalism, Karen Armstrong, Fundamentalism groups

\begin{abstract}
Abstrak
Salah satu perkembangan pada akhir abad kedua pulub adalah munculnya di setiap tradisi agama sebuah kesalehan militan yang secara populer disebut "fundamentalisme". Istilah ini juga dipakai untuk menunjukkan sebuah gerakan baru dalam kebangkitan Islam. Karen Armstrong membuat tiga karakteristik gerakan fundamentalisme, termasuk di dalamnya fundamentalisme Islam. Pertama, ideologi dan teologi gerakan ini berakar dari ketakutan. Kedua, gerakan-gerakan ini bukanlah sebuah hal kuno yang datang dari masa lampau, mereka adalah gerakan modern, inovatif dan memodernkan. Ketiga, kelompok fundamentalisme memiliki pemahaman agama secara tekstual. Perspektif Armstrong tentang fundamentalisme Islam ini berimplikeasi pada Front Pembela Islam (FPI) dan Majelis Mujabidin Indonesia (MMI) yang dapat diidentifikasi sebagai kelompok fundamentalisme Islam di Indonesia. Raison d'etre FPI dan MMI yang hadir sebagai respon (baca: ketakutan) atas kekuatan-kekuatan asing yang mengancam dan membuat umat Islam mengalami penderitaan panjang; bentuk pergerakan dan aksi FPI dan MMI yang begitu terorganisir dan menggunakan semangat massa untuk merespon permasalahan-permasalahan aktual di masyarakat yang terkadang luput oleh aparat; serta penafsiran konsep amar ma'ruf nabi munkar yang diusung oleh FPI dan penegasan MMI terkait larangan penggunaan nalar dalam interpretasi teks, membuat kedua kelompok ini sah sebagai kelompok fundamentalisme dalam kerangka analisis Karen Armstong.
\end{abstract}

Kata Kunci: Fundamentalisme Islam, Karen Armstrong, Kelompok Fundamentalisme

\section{Introduction}

A religion not only has a function to introduce humans to God, but also socially teaches the values that are in accordance with the essence of humanity. This means that with religion, humans can wisely know who their creator is, the pattern of worship to the creator, and how the values of the religion can be implemented in the social life of its 
adherents. Based on these facts, religion is used as the ultimate foundation for solving humanitarian problems socially, politically, culturally or in the nuances of religion itself. The description of the functions of religion above is a picture of the ideal function of religion for humans that leads humans towards the path of salvation that they aspire to ${ }^{1}$.

Normatively, a religion teaches peace and harmony. However, when the message of religion is translated into diverse social realities, religion will change to historicalsociological tendency. When it is applied in reality, the religion is run and practiced in frightening and terrifying way ${ }^{2}$. As Charles Kimball said when people committed crimes in the name of religion, at that time the religious teachings turned to be corrupt, vile and horrible. Kimball also mentioned that there were five signs that could make religion corrupt and vile. First, religion claimed its truth as absolute and the only truth. Second, there was a blind obedience to their religious leaders. Third, humans had the tendency to want an ideal era. Fourth, religion justified all means in achieving its goals. Fifth, religion called for holy war ${ }^{3}$.

The variety of violence and terrorism in the name of religion could be seen from several cases such as the Bali bombing (2002), the Marriot Jakarta Hotel bombing (2003), the Madrid bombing (2004), and the emergence of the Islamic State of Iraq and Syria (ISIS) which declared the establishment of the Islamic Caliphate in Iraq and Syria in 2013, along with the massive media coverage of inhumane actions they carried out. Those various actions

${ }^{1}$ Muhammad Idrus, 'Fundamentalisme sebagai Ideologi Transisi', Unisia, 25.4 (2002), 207.

${ }^{2}$ Herdi Sahrasad dan Al Chaidar, Fundamentalisme, Terorisme dan Radikalisme Perspektif atas Agama, Masyarakat dan Negara (Jakarta: Freedom Foundation \& CSS UI, 2017), p.62

${ }^{3}$ Charles Kimball, Kala Agama Jadi Bencana, terj. Nurhadi (Bandung: Mizan, 2003), p.15-21 brought up an image that terrorism was originated from religious teachings, in this case Islam ${ }^{4}$.

According to Karen Armstrong, the bombing of the World Trade Center (WTC) and the Pentagon on September 11, 2001 had become a historical record that changed the world. This attack was even said to be the most devastating attack by fundamentalists against secular modernity until now. For the first time, the people of the United States were attacked by foreign enemies in their own homeland; not by a nation or a state and not by nuclear missiles, but by religious extremists who only held pocketknives and cutters ${ }^{5}$.

Since the events of September 11, 2001, which were the tragedy of building bombing, the world public opinion accused al-Qaida group led by Osama Bin Laden as the mastermind behind the incident. This group was suspected to have international networks, as a terrorist group, a hard-line group and to use violent ways to achieve its goals based on religion ${ }^{6}$.

The horrific September attacks showed that when people began to use religion to justify the hatred and murder, and to abandon the compassion in all the world major religions, in this case it could encourage moral darkness that endangered humanity ${ }^{7}$. Seeing this phenomenon, religion was sticking out in cases of violence. People had even pointed out that the culprits were those who embraced fundamentalist religion (Islam). This term was embedded in Islamic groups that were considered literalist and cannot accept the

4 Selvia Santi, 'Terorisme Dan Agama Dalam Perspektif Charles Kimball', Jurnal ICMES, 1. 2 (2017), 188

${ }^{5}$ Karen Armstrong, Berperang Demi Tuban: Fundamentalisme dalam Islam, Kristen dan Yabudi, terj. Sahio Wahono, dkk, (Jakarta: Mizan \& Serambi Ilmu Semesta, 2013), p. 8

${ }^{6}$ Aden Wijdan SZ, 'Fundamentalisme Islam: Kecendrungan antara Menafsirkan Realitas dan Doktrin', UNISLA, 25.5 (2002), 220

7 Armstrong. 
existence of others, even though this term was actually unknown in the Islamic world ${ }^{8}$.

The not neutral and biased patterns in using the term fundamentalism also appeared in the mass media coverage. Both Western news agencies and mass media in Muslim countries, the term fundamentalism was used negatively to refer to "hard-line" Islamic movements as such as in Libya, Algeria, Lebanon and Iran. As a result, the term fundamentalism now tended to be interpreted as an Islamic group that strived to achieve its goals by using violent ways?. This impression was actually the result of Western influence which since the 17th century the Westerners had called Islam with various stereotypicalstigmatic nicknames such as Islamic militancy, Islamic radicalism, Islamic fundamentalism, jihad and so forth ${ }^{10}$.

Basically, fundamentalism was found in almost all religions both in mindset and movement and it was also found in both Abraham religion, namely Judaism, Christianity and Islam, and non-Abraham religion, such as Hinduism, Buddhism, Shaykh and so forth. Besides in the religious environment, fundamentalism also appeared in the secular environment. Therefore, the term fundamentalist capitalism, fundamentalist fascism, and so on were also well-known ${ }^{1}$

This paper focused on discussing Islamic fundamentalism based on Karen Armstrong's perspective and its implications for identifying fundamentalism movements in Indonesia. The reason why the author chose the character

8Syamsurijal, 'Kekerasan Berbingkai Agama: Menelusuri Genealogi dan Perkembangan Fundamentalisme dalam Dunia Islam', Al-Fiker, 20. 1 (2016), 34.

'Yusril Ihza Mahendra, Modernisme dan Fundamentalisme dalam Politik. Islam (Jakarta: Paramadina, 1999), p. 8

${ }^{10}$ Maimun Fuadi, 'Fundamentalisme dan Inklusifisme dalam Paradigma Perubahan Keagamaan', Jurnal Substantia, 15. 1 (2013), 115.

${ }^{11}$ Fauzan, 'Fundamentalisme dalam Islam', $A$ AdYan, 5. 1, (2010), 47.
Karen Armstrong because she is a female orientalist thinker who has an objective assessment as an outsider (observer from outside) in solving this discussion of fundamentalism, as well as has written many books related to religion.

\section{Understanding the Islamic Fundamentalism}

Etymologically, the Great Dictionary of Indonesian Language or KBBI mentions the word 'fundamentalism' derived from the word 'fundamen' which means principle, basic nature, and foundation. ${ }^{12}$ In English, the word 'fundamental' means the principal. ${ }^{13}$ Fundamentalism in Arabic is 'ushuliyab' derived from the word 'al-ashlu' that means 'the basis of something' and 'honor' ${ }^{14}$

Fundamentalism is a term that has a level of meaning complexity in religious discourse. Fundamentalism has positive definition in which fundamentalism is identical to the efforts of realization and function of the religion in society and has negative definition which is identical to violence, radicalism and so on $^{15}$.

Basically, the term fundamentalism is used in a different meaning. First, fundamentalism in theological sense specifically refers to certain views about the scriptures and how they are formed. Second, fundamentalism is used in a philosophical sense in which it specifically refers to hostility towards the use of critical methods to approach the study of the scriptures. Third, fundamentalism contains sociological aspects related to the phenomenon

${ }^{12}$ Departemen Pendidikan dan Kebudayaan RI, Kamus Besar Bahasa Indonesia (Jakarta : Balai Pustaka, 1991), p. 281

13Jonh M.Echols dan Hassan Shadily, Kamus Bahasa Inggris-Indonesia (Jakarta: PT Gramedia,1979), p. 260

${ }^{14}$ Muhammad Imarah, Fundamentalisme dalam Perspektif Pemikiran Barat dan Islam (Jakarta: Gema Insani Press, 1999), p.12-13

${ }^{15}$ Badarus Syamsi, 'Konflik dan Kontestasi Fundamentalisme dan Liberalisme para Pembela Tuhan', Refleksi, 13.1 (2011), 100 
of sectarianism or membership in a group which considers the people who do not belong to their group as not "true believers". Fourth, fundamentalism is used in a historical sense which means "religious conservative" or trying to return to the origin of a faith: "return to foundation" (fundamental) is the main call. Fifth, fundamentalism is often used in a political sense, which refers to the efforts to carry out a revolution in the name of religion ${ }^{16}$.

The term fundamentalism is not derived from the vocabulary in Muslim societies. This term was originally raised by Western academics in the historical context of their religious struggle, especially American Protestant Christians. The term was later published in a pamphlet entitled "The Fundamentals of the Faith" which published in America in the 1920s. In the pamphlet, conservative Protestants called back what they believed to be the core of Protestant truth in order to face the spirit of a liberal and progressive era. The term fundamentalism is then used to identify Protestant groups who are anti-modernity ${ }^{17}$.

The term Islamic fundamentalism in the Westerners began to be popular since the outbreak of the Iranian Revolution in 1979 against the United States which they called The Great Satan. The term was widely spread due to the use of popular journalism, especially by Western media. According to Asghar Ali Engineer, there were two reasons why Islamic fundamentalism attracted the attention of Western media. First, the internal reason was that the characteristics of Islam itself which was the most comprehensive religion. Therefore, every movement that was based on Islam always governed his entire life, including trivial matters. Second, the external reason was

\footnotetext{
${ }^{16}$ Nor Huda Ali, 'Gerakan Fundamentalisme Islam di Indonesia', Tamaddun, 14. 2 (2015), 123-124.

${ }^{17}$ Steve Bruce, Fundamentalisme Pertauatan Sikap Keberagamaan dan Modernitas (Jakarta: Erlangga, 2000), p. 15; Imarah.
}

that there was the constellation of the political world. This was because Western Asian countries as the heart of Islam were the strategic countries as oil producers. Western countries, whose economy was highly dependent on oil, were very sensitive to the development of this region. ${ }^{18}$ Since then, the term fundamentalism had been used to generalize various Islamic movements in various parts of the Islamic world as a wave of Islamic revival ${ }^{19}$.

In addition, the Western writers generally viewed the Islamic fundamentalism with a full bias, who considered every discourse and radical protest against the establishment through violent ways as Islamic fundamentalism. Therefore, some Muslims rejected the use of the term Islamic fundamentalism. The rejection of groups in the Islamic environment against the use of the term fundamentalism could be found from their reluctance to use the term, so it was not surprising that Middle Eastern groups preferred to use the term al-Ushulliyah alIslamiyyah (Islamic fundamentalism), al-Ba'th al Islam (Islamic Revival), and al-Harakah alIslamiyah (Islamic movement). On the other hand, the groups that did not like them were called muta'assibin (fanatical groups) or mutatarrifin (radical/extreme groups) ${ }^{20}$.

Responding to the various pros and cons among academics related to the term fundamentalism above, Karen Armstrong also acknowledged that the term was indeed imperfect. However, Armstrong also considered that the term fundamentalism as a useful mark for movements which were different but had strong similarities. Citing a monumental book entitled Fundamentalism

${ }^{18}$ Asghar Ali Engineer, Islam dan Teologi Pembebasan, terj. Agung Prihantoro (Yogyakarta: Pustaka Pelajar, 1995), p. 56

${ }^{19}$ Maimun Fuadi, 'Fundamentalisme dan nklusifisme dalam Paradigma Perubahan Keagamaan', Jurnal Substantia, 15. 1 (2013), 117

${ }^{20}$ Ali. 
Project by Martin E. Marty and R. Scott Appleby, amounting to 6 volumes, Armstrong said as follows:

"All fundamentalisms follow a certain pattern. They are a form of strengthened spirituality, appearing in response to a perceived crisis. They are involved in conflicts with enemies whose secular beliefs and policies seem hostile to religion itself. Fundamentalists do not consider this battle a conventional political struggle. They experience it as a cosmic war between the forces of good and the forces of evil. They worry about annihilation, and try to strengthen their beleaguered identity by picking up certain teachings and practices from the past. To prevent vilification, they often withdraw into themselves from ordinary people to create a counter-culture, but the fundamentalists are not impractical dreamers ... In the end, they strike back and try to purify an increasingly skeptical world. "21.

What Karen Armstrong revealed through her quotation on the work of Martin E. Marty and R. Scott Appleby above, was clearly seen in her analysis of Islamic fundamentalism in Egypt and Iran.

\section{The Characteristics of Islamic Fundamentalism based on Karen Armstrong's Perspective}

Based on all her various works, it could be found that Armstrong had three characteristics to define the movement of fundamentalism, including Islamic fundamentalism. First, the movements of ideology and theology came of the fear. To avoid secularism that could eliminate fundamentalists, they formulated doctrines, erected the barriers and dissociated the believers from the seemingly exciting modern world. Second, these movements were not old thing that come from the past, they were modern, innovative and modernizing movements ${ }^{22}$. Third, fundamentalism had a textual understanding of religion.

The following explanation expounds about the characteristics of Islamic fundamentalism according to Karen Armstrong:

\section{a) Coming of the Fear}

Many Islamic fundamentalists felt the fear and the anxiety and often distorted the traditions they were trying to defend. The modern world, which seemed so exciting to the liberals, seemed to be godless, empty of meaning, and even devilish to a fundamentalist ${ }^{23}$.

At the end of the 19th century, it was clear that modernization, which was initiated by Western countries, was in fact not a solution that could overcome all humanitarian problems as many people had expected. The modernization actually made people feel scared for no reason, at the same time felt emptiness and the emptiness made the life meaningless.

The Modernity had a serious impact on Muslims. In the Egyptian region, Armstrong referred to the figure of Jamal al-Din (18391897), a Shia follower, who preferred to call himself "al-Afghani", the Afghans. Al-Afgani was actually worried about the power and the authority of Britain and other Western countries that have dominated the world, because they believed that such power and authority would ultimately destroy the Islamic world. In Cairo in 1871, al-Afgani educated Muslims to unite under the auspices of Islam and used the religion to fight Western imperialism. Al-Afghani's ideas formed a movement called Pan-Islamism.

In 1899, Muhammad Abduh was appointed as a mufti in Egypt, the main consultant on Islamic law in his country. Abduh used his position as a mufti to reform traditional religious education because he

${ }^{21}$ Armstrong.

${ }^{22}$ Armstrong.
${ }^{23}$ Armstrong. 
believed that students would not be able to play a full role in the modern society if they did not gain knowledge. Armstrong explained that modernization was a destructive attack, which reduced God's influence in politics, law, education and economics.

Besides Muhammad Abduh, another figure who claimed to take action on all the chaos arising from the modernization process in Egypt was Hasan Al-Banna. The modernization in Egypt has alienated them from religion, al-Banna then formed an army for the message of Islam, Armstrong revealed that it was at this time that the Ikhwanul Muslimin formed.

The Ikhwanul Muslimin eventually became a force and was a major actor in the Egyptian political scene. However, this organization had a terrorist force called alJihaz al-Sirri (secret agency), founded in 1943. Armstrong did not reveal al-Banna's reaction to the terrorist force that was contrary to the beginning vision and mission of the formation of that organization. Armstrong obviously saw that al-Banna was unable to control the terrorist force that triggered a series of events that resulted in damaging, self-death and tarnishing the name of the Ikhwanul Muslimin and the destruction of that organization.

\section{b) Modern, Innovative and Modernizing Movements}

When Europeans began to develop a new type of society based on technology that produced unlimited resources, humans all over the world felt that they were in a dramatically changing state. The old forms of religion were no longer suitable for them such as the forms of religion were no longer able to become the enlightenment and consolation that seem to be needed by humans. As a result, men and women try to find the new ways of religion like the reformers and the Prophet era. They tried to build the understanding based on the past understanding in a way that would advance the humans in a new world that they created for themselves and this was one of the modern experiments of fundamentalism ${ }^{24}$.

Khomeini's theory of the wilayatul faqih was a surprising and revolutionary reversal of Shi'a tradition. The Muslim thinkers preached a theology of liberation and produced an antiimperialist ideology that was in harmony with the other Third World movements of their time. This was also a part of the fundamentalist uprising against the secular domination; how to bring God back into the political scene from which He was ostracized. In various ways, fundamentalists have rejected the separations of modernity (between church and state, the secular and the profane) and tried to re-create a lost wholeness. This battle for the sake of God was an attempt to fill the emptiness in the hearts of people based on scientific rationalism ${ }^{25}$.

\section{c) The Textual Understanding of Religion}

Etymologically, the word 'textual' means 'literal'. Terminologically, textual understanding is an understanding that is oriented to the text itself. Therefore, through this approach the revelation of god is understood through the linguistic approach, regardless of the sociohistorical setting, when and where the revelation is revealed ${ }^{26}$.

The literal understanding itself is divided into two: First, closed literalism that is limiting the meaning of a text or texts of other meanings that are equally likely to be true, such understanding is adopted by Ibn Abd alWahhab. The literalism of Ibn Abd al-Wahhab has broken the holy texts (read: the Qur'an and Sunnah) from the context of the treatise period and the context of the reading period. This understanding was a reduction and distortion of the text message itself. The closed literal recitation of sources of Islamic teachings raises

${ }^{24}$ Armstrong.

${ }^{25}$ Armstrong.

${ }^{26}$ M. Sadik, 'Al-Qur'an Dalam Pendekatan Pemahaman Tekstual dan Kontekstual', Hunafa, 6. 1 (2009), 55. 
rigid, hard and extreme understandings so that it rejects rationalism, a diverse tradition of Islamic intellectual property which is very rich. Second, open literalism is the search for the meaning of texts widely and openly in question but without being rigidly bound. This literalism was represented by Ibn Arabi, the literal texts must be maintained and put first ${ }^{27}$.

In the opinion of other thinkers such as Youseff M. Choueiri stated that intellectually and politically fundamentalism supported a creative interpretation of the sacred text, both the Bible and the Qur'an. However, such an interpretation was entirely non-critical, apologetic and didactic. As a result, there was excessive hatred of historical criticism as well as all attempts to question the truth of certain events or the validity of some teachings indirectly ${ }^{28 .}$

The typical mindset of fundamentalists was the belief that there was a way to interpret reality. Fundamentalism in Islam ignored the pluralism of the Qur'an and the extremists cited the verses of the Qur'an that are more aggressive to justify violence, and blatantly ignore many more verses that call for peace, tolerance, and forgiveness. The fundamentalists believed that they were fighting in the name of God. Making purely human historical phenomena, such as "family values", "Holy Land", "Islam" something sacred and of absolute value mean idolatry and, as usual, idols force them to try to destroy their opponents. ${ }^{29}$

\section{The Identification of Fundamentalist Groups in Indonesia}

The Islamic reform movement which was identical with the term fundamentalism had

27 Agus Ali Dzawafi, 'Pemahaman Tekstual dan Implikasinya Terhadap Gerakan Dakwah Front Pembela Islam (FPI)', Adrikera, 3.1 (2012), 30.

${ }^{28}$ Youssef M. Choueiri, Islam Garis Keras: Melacar Akar Gerakan Fundamentalisme, terj. Humaidi Syuhud dan M. Maufur, (Yogyakarta: Qonun, 2003), p. x

29 Karen Armstrong, Masa Depan Tuban: Sanggahan terhadap Fundamentalisme dan Ateisme, terj. Yuliani Liputo (Bandung: Mizan, 2013), p. 470-471 experienced the development of the orientation of the movement which was initially oriented towards the ideological domain developed into a movement oriented to politics, social, and culture ${ }^{30}$. In Indonesia, the term fundamentalism had also been very popular, and was embedded in several groups/ organizations such as the Islamic Defenders Front (FPI) and the Indonesian Mujahidin Council (MMI).

The characteristics of Islamic fundamentalism, as described by Karen Armstrong above, could be used as a basis for categorizing FPI and MMI as an Islamic fundamentalist group.

\section{a) Islamic Defenders Front (FPI)}

As an organization, FPI was officially established on August 17, 1998, at the AlUmm Islamic boarding school in Kampung Utan, Ciputat, South Jakarta. This organization was founded by a number of habibs, scholars, preachers, Muslim activists and Muslim people. The figure who spearheaded the founding of FPI was Habib Muhammad Rizieq Shihab. Not only in Jakarta over time, FPI sympathizers have multiplied and established FPI in areas such as Surakarta, Bandung and Yogyakarta and almost every city in Indonesia ${ }^{31}$.

The socio-political background of the establishment of FPI include: First, the long suffering experienced by Indonesian Muslims as a result of human right violations committed by the ruler. Second, the failure of the state agency upholding the law and guarantees the public order. Third, there was an obligation for every Muslim to preserve and maintain the dignity of Islam. Fourth, there was an obligation for every Muslim to uphold amar makruf nabi munkar. The background of the

30 Kunawir Basyir, 'Menimbang Kembali Konsep Gerakan Fundamentalisme Islam di Indonesia', At-Tabrir, 14. 1 (2014), 33.

31 Machfud Syaefudin, 'Reinterpretasi Gerakan Dakwah Front Pembela Islam (FPI)', Jurnal Ilmu Dakwah, 34. 2 (2010), 261. 
forming of FPI was inseparable from the events of reform as a momentum for social and political change in Indonesia ${ }^{32}$.

Since FPI was officially declared by scholars who had a common mission to uphold the amar ma'ruf nahi munkar, FPI has carried out the movements that were done to keep the prosperity of Muslims in Indonesia and saved the nation from the moral crisis after the New Order. FPI became very famous because of its controversial actions from 19982012. This was proven by the existence of da'wah movements carried out to uphold the amar ma'ruf nabi munkar, especially those carried out by the army of the military, namely the Islamic Defending Army. The series of actions to close nightclubs, prostitution, alcohol and drug transactions and places claimed to be immoral, threats to certain citizens, arrests (sweeping) of certain citizens, conflicts with other faith-based organizations were the images of FPI which were most often shown in mass media ${ }^{33}$.

The concept of amar ma'ruf nabi munkar which was firmly held by FPI departed from a hadith which was interpreted to be very textual, "Whoever see the evil thing, prevent it by using his/her hands, if he/she can't, prevent it using his/her voice, if he/she can't, prevent it with his/her heart, and that is the weakness of faith."

FPI interpreted the word 'man' (من) which meant "who" as 'am' (general) included anyone, scholars, officials or the people so that the hadith demands all parties who saw munkar or evil thing must change it. The word 'minkum' (منكم) which meant 'whosoever' was only limited to Muslims because Rasulullah SAW used that word to address to the person who spoke to him that was the Muslims. Therefore, any Muslim who saw munkar had obligation to

${ }^{32}$ Syaefudin.

${ }^{33}$ Saeful Anwar, 'Pemikiran dan Gerakan Amr Ma'ruf Nahy Munkar Front Pembela Islam (FPI) di Indonesia 1989-2012', Teosofi, 4.1 (2014), 246. change it. The word 'biyadib' (بيده) which meant "with his hands" referred to the real meaning. It meant to change by using the real hand, which was, a limb from the tip of the finger to the armpit limit. This real meaning was strengthened with the understanding of the word (من) above, so that it included the hands of the ulama, umara (leader) and the hands of ordinary people. It was added with the word 'lisan' (لسان) and qalb (لبان) which meant heart. Both of them showed the part of body's organs so that it strengthened that the word 'biyadib' had the meaning of the part of the body's organs as well ${ }^{34}$.

FPI's understanding of the hadith amar ma'ruf nahi munkar could be categorized as a textual understanding because it only looked at what was written (spoken, written) without giving an analysis about the context of when and where this hadith was revealed. In other words, FPI's understanding of the above hadith fulfills all the criteria/ characteristics of textual understanding ${ }^{35}$.

\section{b) Indonesian Mujabidin Council (MMI)}

Indonesian Mujahidin Council (MMI) was an organization declared through the First Mujahidin Congress in Yogyakarta on Jumadil Ula 5-7,1421 H, which coincided on August 57, 2000, which created the Yogyakarta Charter whose contents; (a) It's an obligation for Muslims in Indonesia and generally in the world to implement Islamic sharia; (b) Refusing all ideologies that are contrary to Islam that result in shirik, nifaq and violating human rights; (c) Building a strong shof mujahidin unity which is strong domestically, regionally and internationally (between nations); (d) Establishing a mujahidin council towards the realization of Imamat (khilafah)/ leadership of the ummah, both in Indonesia and in the unity of the Muslim world; (e) Calling the Muslims to mobilize da'wah and

\footnotetext{
${ }^{34}$ Dzawafi.

${ }^{35}$ Dzawafi.
} 
jihad throughout the world for the sake of the establishment of Islam as rahmatan li al'alamin ${ }^{36}$.

There are three reasons that encourage and are the background of the first Indonesian Mujahidin congress held: historical reason, shar'iyah reason and situational reason. First, historically, the journey of Islam was first defended by a group and that group was not secretive which means open. Second, the Mujahidin Council concocted where there was a mosque group so that the theme at that time was the enforcement of Islamic shar'iyah. The enforcement of Islamic Shar'iyah from the era of Gus Dur to Jokowi has not changed. In Shar'iyah, the enforcement of shar'iyah was not an individual obligation but a joint obligation. How did people congregate if there was no congregation? So that upholding Islamic law became an icon of each individual. There were no Muslims who reject Islamic Shar'iyah. Third, situationally (Post-reform), all competed to express their voice, such as the demonstration of prostitutes, LGBT, and many Islamic parties were established at that time. Can Islam be victorious with these parties? It turns out that the parties have their own goals so that the mosque youth who are members of the mosque youth coordinator sparked the idea of holding a congress which is now known as the Mujahidin Congress ${ }^{37}$.

The most visible main theme in this movement is to return the Qur'an and Sunnah as the main reference in religious life, so that everything in the Qur'an and Sunnah cannot be developed through logical reasoning, but must be understood and practiced as it is. The consequence of this understanding is the interpretation of the Qur'an and Sunnah

36 Rosidin, Relasi Sosial Majelis Mujabidin dalam Konstelasi Kebangsaan (Semarang: Balai Penelitian dan Pengembangan Agama, 2002), p. 107

37 Moh. Dliya'ul Chaq, 'Pemikiran Hukum Gerakan Islam Radikal: Studi Atas Pemikiran Hukum dan Potensi Konflik Sosial Keagamaan Majelis Mujahidin Indonesia (MMI) dan Jama'ah Anshorut Tauhid (JAT)', Tafaqquh, 1.1 (2013), 23-24 becomes rigid and textual because of the eliminating of the role of logical reasoning. The ideology of MMI such stated above claimed that the shar'iyah is all the rules of life and the guidance taught by the Islamic religion that came from the Qur'an and the Sunnah of the Prophet Muhammad SAW ${ }^{38}$.

The main struggle of MMI is the enforcement of Islamic law in the Indonesian state system. Therefore, MMI is one of the parties who most fought for the Jakarta Charter in the 1945 Constitution amendment and viewed the past seven-word deletion as a betrayal towards Muslims. MMI promotes the existence of the Khilafah State to enact Islamic law. In the campaigns so far, MMI has always formed an alliance with all Muslims to uphold Islamic law. As for ideologies outside of Islam, MMI very firmly refused to "bow down" and even oppose it as an apostasy ${ }^{39}$.

\section{Conclusion}

Thus, it could be concluded that the characteristics of Islamic fundamentalism according to Karen Armstong consists of three things: First, the group of ideology and theology came of the fear. This characteristic could be seen from the mainspring of FPI and MMI who were present as a response (read: fear) for foreign powers that threatened and made Muslims suffered for a long time. Second, these groups were not old thing that came from the past, but they were modern, innovative and modernizing movement. This character could be seen from the form of movements and actions of FPI and MMI that were so organized and used the spirit of the masses to respond to actual problems in society that were sometimes missed by the authorities. And third, this group had a textual understanding of religion. This characteristic was clearly seen in the interpretation related to

\footnotetext{
${ }^{38}$ Chaq.

39 Ahmad Shidqi, Sepotong Kebenaran Milik Alifa
} (Yogyakarta: Impulse, 2008), p.73 
the concept of amar ma'ruf nabi munkar which is promoted by FPI, and the affirmation of MMI related to the prohibition on the use of reason in text interpretation.

\section{References}

\section{Books}

Armstrong, Karen, Berperang Demi Tuban: Fundamentalisme dalam Islam, Kristen dan Yabudi, terj. Sahio Wahono, dkk, (Jakarta: Mizan \& Serambi Ilmu Semesta, 2013)

Armstrong, Karen, Masa Depan Tuban: Sanggahan terhadap Fundamentalisme dan Ateisme, terj. Yuliani Liputo (Bandung: Mizan, 2013)

Bruce, Steve, Fundamentalisme Pertauatan Sikap Keberagamaan dan Modernitas Jakarta: Erlangga, 2000)

Choueiri, Youssef M., Islam Garis Keras: Melacar Akar Gerakan Fundamentalisme, terj. Humaidi Syuhud dan M. Maufur, (Yogyakarta: Qonun, 2003)

Departemen Pendidikan dan Kebudayaan RI, Kamus Besar Bahasa Indonesia (Jakarta : Balai Pustaka, 1991)

Echols, Jonh M. dan Hassan Shadily, Kamus Bahasa Inggris-Indonesia (Jakarta: PT Gramedia,1979)

Engineer, Asghar Ali, Islam dan Teologi Pembebasan, terj. Agung Prihantoro (Yogyakarta: Pustaka Pelajar, 1995)

Imarah, Muhammad, Fundamentalisme dalam Perspektif Pemikiran Barat dan Islam (Jakarta: Gema Insani Press, 1999)

Kimball, Charles, Kala Agama Jadi Bencana, terj. Nurhadi (Bandung: Mizan, 2003)

Mahendra, Yusril Ihza, Modernisme dan Fundamentalisme dalam Politik Islam (Jakarta: Paramadina, 1999)

Rosidin, Relasi Sosial Majelis Mujahidin dalam Konstelasi Kebangsaan (Semarang: Balai Penelitian dan Pengembangan Agama, 2002)
Sahrasad, Herdi dan Al Chaidar, Fundamentalisme, Terorisme dan Radikalisme Perspektif atas Agama, Masyarakat dan Negara,(Jakarta: Freedom Foundation \& CSS UI, 2017)

Shidqi, Ahmad, Sepotong Kebenaran Milik. Alifa (Yogyakarta: Impulse, 2008)

\section{Journals}

Ali, Nor Huda, 'Gerakan Fundamentalisme Islam di Indonesia', Tamaddun, 14. 2 (2015), 123-124

Anwar, Saeful, 'Pemikiran dan Gerakan Amr Ma'ruf Nahy Munkar Front Pembela Islam (FPI) di Indonesia 1989-2012', Teosofi, 4.1 (2014), 246

Basyir, Kunawir, 'Menimbang Kembali Konsep Gerakan Fundamentalisme Islam di Indonesia', At-Tahrir, 14. 1 (2014), 33

Chaq, Moh. Dliya'ul, 'Pemikiran Hukum Gerakan Islam Radikal: Studi Atas Pemikiran Hukum dan Potensi Konflik Sosial Keagamaan Majelis Mujahidin Indonesia (MMI) dan Jama'ah Anshorut Tauhid (JAT)', Tafaqquh, 1.1 (2013), 2324

Dzawafi, Agus Ali, 'Pemahaman Tekstual dan Implikasinya Terhadap Gerakan Dakwah Front Pembela Islam (FPI)', Adrikera, 3.1 (2012), 30

Fauzan, 'Fundamentalisme dalam Islam', AlAdyan, 5. 1, (2010), 47

Fuadi, Maimun, 'Fundamentalisme dan Inklusifisme dalam Paradigma Perubahan Keagamaan', Jurnal Substantia, 15. 1 (2013), 115

Idrus, Muhammad, 'Fundamentalisme sebagai Ideologi Transisi', Unisia, 25.4 (2002).

Sadik, M., 'Al-Qur'an Dalam Pendekatan Pemahaman Tekstual dan Kontekstual', Hunafa, 6. 1 (2009), 55

Santi Selvia, 'Terorisme Dan Agama Dalam Perspektif Charles Kimball', Jurnal ICMES, 1.2 (2017), 188 
Syaefudin, Machfud, 'Reinterpretasi Gerakan Dakwah Front Pembela Islam (FPI)', Jurnal Ilmu Dakwah, 34. 2 (2010), 261.

Syamsi, Badarus, 'Konflik dan Kontestasi Fundamentalisme dan Liberalisme para Pembela Tuhan', Refleksi, 13.1 (2011), 100.
Syamsurijal, 'Kekerasan Berbingkai Agama: Menelusuri Genealogi dan Perkembangan Fundamentalisme dalam Dunia Islam', Al-Fikr, 20.1 (2016), 34

Wijdan SZ, Aden, 'Fundamentalisme Islam: Kecendrungan antara Menafsirkan Realitas dan Doktrin', UNISLA, 25. 5 (2002), 23 